\title{
Investigation into the influence of humic substances on the potentially pathogenic flora of fish
}

\author{
Natalia Matvienko', \\ Natalia Svechkova ${ }^{2}$ \\ ${ }^{1}$ Institute for Fisheries UAAS, \\ Obukhivska St. 135, Kyiv, \\ 03164, Ukraine \\ ${ }^{2}$ Department of Agricultural \\ Development of Kyiv Regional \\ State Administration, \\ V. Vasylkivska St. 13/1, Kyiv, \\ Ukraine, 01004
}

\begin{abstract}
The purpose of this research paper was to study the influence of humic substances on the potentially pathogenic microbial flora extracted from various species of fish. All the substances were obtained by the original technology of the Djala Gold Company, Dnepropetrovsk, Ukraine. Investigations were based at the Department of Ichthyopathology of the Institute of Fisheries of the National Academy of Agrarian Sciences of Ukraine. The results of the investigation showed that such a substance as potassium humate had no significant impact on the growth of pathogenic microorganisms, and in some cases contributed to a more intensive growth of the bacterial flora. At the same time, it does not have a negative impact on the autochthonous heterotrophic flora of the intestine of such fish as a carp (Cyprinus carpio) and a channel catfish (Ictalurus punctatus). Such substances as the compound of silver humate and methylene blue are characterized by a significant antimicrobial activity; they are promising for further research and application in the complex therapy and in the treatment of bacterial infections of fish.
\end{abstract}

Keywords: humic substances, pathogenic microbial flora of fish, channel catfish (Ictalurus punctatus), carp (Cyprinus carpio)

\section{INTRODUCTION}

Humic substances can be found in nature almost everywhere as they are the main organic component of soil, water, and solid fuels. Humic acids are found in such rocks as brown coal, putrid mud, and peat. Brown coal contains up to $86 \%$ of humic acids, that is, brown coal mining wastes are the major source of humic substances, so this

* Corresponding author. Email: mnarine73@ukr.net fact can solve numerous environmental problems (Orlov, 1997; Orlov, Bezuglova, 2000; Inisheva, Yudina, 2005). Modern scientific research has found that humic substances are harmless to animals and humans, they have no allergenic, anaphylactogenic, teratogenic, embryotoxic, or carcinogenic effects when used in recommended doses (Bollag, Mayers, 1992; Steinberg, 2003). Humic substances (HS) are presented by complex polydisperse compounds of the stochastic nature, possessing biological activity. The investigations 
of the recent decades indicate that the structure and properties of humic substances depend not only on the type of the raw material, but also on the natural occurrence of the source of a particular raw material (Kocabağli et al., 2002; Kucukersan et al., 2005). The antibacterial, anti-inflammatory, antioxidant, hepatoprotective, and antiviral effects of HS were revealed through experiments (Schnitzer, Khan, 1972; Stevenson, 1985; Stepchenko et al., 1991; Bollag, Mayers, 1992; Shermer et al., 1998; Anisimov, Likhatskaya, 2001). However, we have no reliable information regarding the mechanisms of the activity of humic acids towards biological objects.

Neither the developers of the substance nor scientific periodicals have data on the effect of humic substances on the potentially pathogenic microbial flora of fish, and it was this fact that motivated us to conduct our research. The purpose of our investigation was to study the effect of humic substances on the potentially pathogenic microbial flora isolated from different species of fish. The following issues were included in the research: (1) to select the strains of bacteria taken from clinically healthy and diseased fish from the water environment and (2) to examine the sensitivity of the selected microbial flora to humic substances in the laboratory.

\section{MATERIALS AND METHODS}

\section{Diet preparation}

In our investigations, such a substance as "Torfovit" in the form of water-soluble powder or a clear liquid with the specific smell of alkaline peat extract and salty-sweet taste was used. The colour of the liquid varied from brown to dark brown; there was no sludge or it could be found, but only in small amount. The concentration of the substance varied from 5\% to $7 \%$. "Torfovit" contains the polymeric chain of potassium humate which contains 5000-6000 monomers and has a great amount of free radical endings. Being a constituent of the agent, potassium humate is able to form compounds with free radicals and metal ions easily, to form organic and mineral compounds available to be absorbed by fish. In addition, we investigated the effect of such substances as silver humate (aqueous solution of 7\%), humate + methylene blue with metals (aqueous solution of $7 \%$ ), and humate + methylene blue and silver on the microbial flora of fish. All the substances were obtained using the original technology of the Djala Gold Company, Dnepropetrovsk, Ukraine.

\section{Experimental design}

The inoculations from the lining of intestines from five specimens of fish were carried out within the period of 72 hours after the last feeding of fish. For this purpose some pieces of the intestine, without residues of orts and mucus, in size of $0.5 \mathrm{~cm}^{2}$ (for carp) and $1 \mathrm{~cm}^{2}$ (for channel catfish) were aseptically isolated and homogenized in a sterile porcelain mortar. The homogenate was suspended in sterile water at a ratio of 1:10 and settled for $10 \mathrm{~min}$, taking $1 \mathrm{ml}$ of the supernatant fluid. Then we prepared the necessary dilution (1100, 1: 1000), adding the tryptone soy agar TSA in amounts of $0.1 \mathrm{ml}$ and $1 \mathrm{ml}$ to the culture medium (Golovin, Bauer, 2003).

In the investigation, we used the live fish, because when the fish is non-living the microbial flora starts to develop, spreading rapidly in tissues and organs. In experiments, we used the scaly carp (Cyprinus carpio) at the age of $0+$ and the channel catfish (Ictalurus punctatus) at the age of $2+$ (Musselius, 1983).

\section{Data analysis}

The microbiological investigations were carried out in several steps:

- primary inoculation of the material based on the Tryptone Soya Agar (TSA), which was incubated in a thermostatically controlled chamber at a temperature of $26^{\circ} \mathrm{C}$ for 24 hours.

- obtaining of pure growth of the microorganisms was carried out by sizing on the TSA. The morphological properties were determined by Labinskaya (Labinskaya, 1978) and Bergey (Zavarzin, 1997).

- determination of the deoxyribonuclease activity of the selected isolates was performed on the DNA agar (Labinskaya, 1978; Dolganova et al., 2005). 
The rapid identification of bacteria was carried out using a standardized test system of API 20E "Bio Merieux" (France). The identification was performed on the basis of 21 biochemical tests.

The inoculations were incubated for 18-24 hours. The results were evaluated visually by comparing the colour of reactions and the colour in the identification table.

The sensitivity of the test bacteria to the agent was determined by the agar diffusion method on the solid medium of TSA (Labinskaya, 1978). The agent was tested on eight bacterial cultures extracted from fish such as the carp and the silver carp. In determining the biological activity by the agar disk technique, the standard $5 \mathrm{~mm}$ diameter discs were prepared from the filter paper and soaked with the solutions of substantial concentration of substances $(2 \mathrm{mg} / \mathrm{ml})$. The degree of sensitivity of the bacteria to the substances was evaluated by the diameter of the growth inhibition zone: the strains, where the degree of sensitivity reached more than $25 \mathrm{~mm}$, were considered to be highly sensitive; in sensitive ones, the degree of sensitivity was $15-25 \mathrm{~mm}$; in the low-sensitive strains, the degree of sensitivity amounted to $10-14 \mathrm{~mm}$; the resistant strains resulted in the degree of sensitivity of $10 \mathrm{~mm}$ or less, or with a complete absence of bacterial development delay. The identification of the deoxyribonuclease activity of the extracted strains of bacteria was carried out on the deoxyribonuclease agar produced by "DIFCO" company, by finding the pellucid zones of deoxyribonucleic acid depolymerizing around the colonies of DNA-positive bacteria. For this purpose, after 48 hours of culturing at $26^{\circ} \mathrm{C}$ the cups with colonies were filled with $0.1 \mathrm{n}$ solution of hydrochloric acid. The clearly visible reaction was detected in 3-5 minutes.

\section{RESULTS}

The primary identification of bacteria isolates was carried out and their morphological and biochemical properties were investigated. The psychrophilic bacteria, belonging to the genera of Pseudomonas, Aeromonas, and Flavobacterium, were predominant in the fish investigated in the cold season. In the warm season, the microbial flora of the skin and the internal organs of the fish were represented by the mesophilic microorganisms, namely various species of bacteria of Micrococcus genera.

Most of the bacteria of the genera of Aeromonas and Flavobacterium tested were taken from the hatchlings and fingerlings of the rainbow trout (Oncorhynchus mykiss), the genera of Pseudomonas and Aeromonas were isolated from the carp, namely, the common carp (Cyprinus carpio); the bacteria of the genera of Yersinia were obtained from sturgeons.

It was established that the bacterial isolates extracted from the outer shell had a low deoxyribonuclease activity, indicating that there was a little amount of the potentially pathogenic microbial flora that was unable to cause the pathological process. The vast majority of the bacterial isolates belong to the normal flora typical for aquatic biological objects. The 7\% aqueous solution of potassium humate was used for the investigation. Eight bacterial cultures isolated from the fish such as carp and silver carp were tested. The microbiological investigations established that $25 \%$ of the microbial flora of the outer shell was represented by the Aeromonas bacteria, 17\% composed the potentially pathogenic bacteria of the genera of Pseudomonas, and 13\% were taken from the bacteria of Flavobacterium genera, which often cause infectious processes when the fish is weak.

It was noted that the potassium humate substance had no effect on the growth of the potentially pathogenic flora of fish and in some cases it could promote the healthy growth of the bacterial flora.

It was worth testing the effect of the agent activity on the bacteria of the gastrointestinal tract of the fish, which contributed to the enhancement of the processes of digestion and metabolism. The investigations were carried out feeding the fish with special combined fodder such as K III-9 for carp and SB-3 for channel catfish, with the addition of the substance. 
The results of the research into the effect of the potassium humate substance on the microbial flora of the intestines of the carp and the catfish are presented in Tables 1 and 2 .

According to the results of the experiments, no significant difference in the effect of the potassium humate substance on the intestinal microbial flora of the carp and the catfish was observed. The amount of the heterotrophic autochthonous microbial flora in the intestinal

Table 1. Research on the intestinal microbial flora of the $\operatorname{carp}\left(0^{+}\right)(M+m, n=5)$

\begin{tabular}{|c|c|c|}
\hline \multicolumn{3}{|c|}{$\begin{array}{c}\text { The overall amount of the heterotrophic bacte- } \\
\text { ria }(\mathrm{TH}) \text { of the microbial cells } / \mathrm{cm}^{2}\end{array}$} \\
\hline \multicolumn{3}{|c|}{ Control } \\
\hline \multirow{3}{*}{$\begin{array}{l}\text { Parts of the in- } \\
\text { testine }\end{array}$} & $\mathrm{I}$ & $21 \pm 6.39$ \\
\hline & II & $32 \pm 2.57$ \\
\hline & III & $60 \pm 2.12$ \\
\hline \multicolumn{3}{|c|}{ Experiment } \\
\hline \multirow{3}{*}{$\begin{array}{l}\text { Parts of the in- } \\
\text { testine }\end{array}$} & I & $49 \pm 1.20$ \\
\hline & II & $41 \pm 2.28$ \\
\hline & III & $72 \pm 2.15$ \\
\hline
\end{tabular}

mucosa was similar and slightly decreased compared to the control, which confirmed the lack of a negative impact of the substance on the heterotrophic autochthonous microbial flora of fish.

The results of the effect of the following substances, namely, silver humate (7\% aqueous solution), humate + methylene blue with metals (7\% aqueous solution), and humate + methylene blue with silver, on the microbial flora of the fish are presented in Table 3.

Table 2. Research on the intestinal microbial flora of the catfish $\left(2^{+}\right)(M+m, n=5)$

\begin{tabular}{ccc}
\hline \multirow{2}{*}{$\begin{array}{c}\text { The overall amount of the heterotrophic bacte- } \\
\text { ria (TH) of the microbial cells } / \mathrm{cm}^{2}\end{array}$} \\
\hline \multicolumn{3}{c}{ Control } \\
\hline \multirow{3}{*}{$\begin{array}{c}\text { Parts of } \\
\text { the intestine }\end{array}$} & I & $16 \pm 3.59$ \\
\cline { 2 - 3 } & II & $28 \pm 1.69$ \\
\hline & III & $40 \pm 2.28$ \\
\hline \multirow{3}{*}{$\begin{array}{c}\text { Parts of } \\
\text { the intestine }\end{array}$} & I & $11 \pm 1.23$ \\
\cline { 2 - 3 } & II & $24 \pm 2.04$ \\
\hline
\end{tabular}

Table 3 . Investigation into the bacteriostatic effect of substances

\begin{tabular}{|c|c|c|c|}
\hline & \multicolumn{3}{|c|}{ Diameter of the stasis areas, $\mathrm{mm}$} \\
\hline & Silver humate & $\begin{array}{l}\text { Humate + meth- } \\
\text { ylene blue with } \\
\text { silver }\end{array}$ & $\begin{array}{l}\text { Humate }+ \text { meth- } \\
\text { ylene blue with } \\
\text { metals }\end{array}$ \\
\hline Test-culture Aerom. & 20 & 15 & * \\
\hline Test-culture Pseudom. & 18 & 14 & * \\
\hline Carp 0507 & - & - & - \\
\hline Carp 0512 & 12 & 15 & 8 \\
\hline Pike 0419/1 & 19 & 12 & * \\
\hline Channel catfish 0532 & 16 & - & 10 \\
\hline Carp 0509 & - & 17 & 6 \\
\hline Carp 0534 & 17 & 14 & 4 \\
\hline Clarid catfish (surface) 0521 & 18 & 14 & * \\
\hline Clarid catfish ( intestine) $0523 / 3$ & 16 & 13 & - \\
\hline Pike 0430 & 18 & 11 & 9 \\
\hline Carp 0513 & 14 & 14 & 10 \\
\hline
\end{tabular}

\footnotetext{
* - partial stasis of test cultures
} 
Ten bacterial strains isolated from various fish species and standard test Pseudomonas and Aeromonas cultures were used for the study. The results of the study on the antimicrobial activity of these substances towards the test cultures indicate that silver humate is the most effective bactericide and the area of microbial flora inhibition (bacteriostasis) ranged from 14 to $20 \mathrm{~mm}$. Humate + methylene blue with silver showed good results when inhibiting the most common bacterial infections of fish caused by Aeromonas and Pseudomonos (the stasis zone was $12-17 \mathrm{~mm}$ ). In the study of low-virulent strains of opportunistic bacteria of fish, the humate + methylene blue complex with metals showed a bacteriostasis zone of 9 to $12 \mathrm{~mm}$.

The results of the research showed that the substances of silver humate and humate with silver + methylene blue were characterized by a significant antimicrobial activity; they are promising both for further research and application in complex therapy and in the treatment of bacterial infections of fish.

\section{DISCUSSION}

The results of our investigation are proved by a number of scientists who have been studying the effect of humic substances. The development of the process of production of humic substances, where humic substances were taken as nanoparticles, was carried out by the scientists of the Far Eastern National University. They studied the composition and properties of nanostructured objects of natural origin extracted from the soil and the prospects of their application (Nesterova et al., 2008). The microbiological laboratory of the department of Samara Federal State-funded Healthcare Institution (FSFHI) "Samara Region Hygiene and Epidemiology Centre" conducted an investigation into the effects of solutions obtained from therapeutic mud of Sergiev mineral waters resort, with varying concentrations of $25 \%$ mud solution on the microbial flora of tonsils, namely St. aureus, St. epider- midis, E. coli, Haemophilus influenzae, St. viridans, Neisseria perflava. The obtained results showed significant bacteriostatic effect of mud solutions at a concentration of $25 \%$ that can be useful for the treatment of joint diseases associated with chronic infectious processes. (Perminov, 2000).

Thus, humic acids and their derivatives possess the ability to enhance the activity of the immune and hematopoietic systems; not only they have a positive effect on the digestibility of nutrients but also increase the average daily weight gain and safety of young animals that should be regarded as a manifestation of the nonspecific effect on the overall resistance of the body (Gorovaya et al., 1995; Chukhareva, 2003). However, most of humic substances used in modern veterinary medicine are applied orally, while the high-molecular polyphenol compounds, when entering the body through the gastrointestinal tract, show the minimal biological activity and undergo the inactivation and decomposition.

\section{CONCLUSIONS}

1. When checking the effect of the potassium humate substance on the potentially pathogenic flora of the fish, we found that this substance had no significant impact on its growth and in some cases it contributed to a more intensive growth of bacterial flora.

2. In the laboratory we noted that the potassium humate substance had no negative impact on the autochthonous heterotrophic flora of the intestine of such fish as the carp and the channel catfish.

3. The results of the investigation showed that both silver humate and methylene blue substances were characterized by a significant antimicrobial activity; they are promising for further research and application in complex therapy and the treatment of bacterial infections of fish. 


\section{References}

1. Anisimov MM, Likhatskaya GN. Some of the chemical and biomedical properties of humic acids. Scientific papers in crop and livestock research. Khabarovsk, 2001; 2: 34-44. Russian.

2. Bollag JM, Mayers K. Detoxification of aquatic and terrestrial sites through binding of pollutants to humic substances. Sci Total Environ. 1992; 117-118: 357-66.

3. Chukhareva NV. Kinetics of thermally activated changes in the composition and properties of peat humic acids. Doctoral thesis. Tomsk. 2003: 1-126. Russian.

4. Dolganova NV, Pershina EV, Khasanova ZK. Microbiology of fish and fish products. Moscow: Mir; 2005. p. 1-224. Russian.

5. Golovin NA, Bauer O. Ichthyopathology. Moscow: Mir; 2003. p. 1-448. Russian.

6. Gorovaya AI, Orlov DS, Shcherbenko OV. Humic substances. Kiev: Naukova Dumka; 1995. p. 1-304. Russian.

7. Inisheva LI, Yudina NV. Humic substances in the biosphere: Materials of the 3rd Russian National Conference; 2005 March; St. Petersburg. p. 31-32. Russian.

8. Kocabağli N, Alp M, Acar N, Kahraman R. The effects of dietary humate supplementation on broiler growth and carcass yield. Poult Sci. 2002; 81(2): 227-30.

9. Kucukersan S, Kucukersan K, Colpan I, Goncuoglu E, Reisli Z, Yesilbag D. The effects of humic acid on egg production and egg traits of laying hen. Vet Med Czech. 2005; 50(9): 406-10.

10. Labinskaya AS. Microbiology with the technique of microbiological research. Moscow: Medicine; 1978. p. 1-394. Russian.

11. Musselius VA. Laboratory course on fish diseases. Moscow: Light and food industries; 1983. p. 1-296. Russian.

12. Nesterova OV, Semal VA, Tregubova VG. Sourcebook of the section reports, poster presentations, and reports of the participants of the contest of scientific works of young scientists. Far Eastern National University, section "Chemistry and chemical technology of nanomaterials" of the International Forum on Nanotechnologies. Vladivostok. 2008: 39.

13. Orlov DS. Humic substances in the biosphere. Scientific papers of Sorovsky Educational periodical in text format. Chemistry. Moscow State University named after Lomonosov M. V.; 1997. Russian.

14. Orlov DS, Bezuglova OS. Biogeochemistry. Rostov-on-Don: Phoenix; 2000. p. 1-42. Russian.

15. Perminov IV. The analysis, classification and prognosis of the properties of humic acids [doctoral thesis]. Moscow. p. 1-117. 2000. Russian.

16. Schnitzer M, Khan SU. Humic substances in the environment. New York: Marcel Decker; 1972. p. 12-17.

17. Shermer CL, Maciorowski KG, Bailey CA, Byers FM, Ricke S. Caecal metabolites and microbial populations in chickens consuming diets containing a mined humate compound. J Sci Food Agric. 1998; 77: 479-86.

18. Steinberg CEW. Ecology of Humic Substances in Freshwaters. Springer; 2003. p. 1-332.

19. Stepchenko LM, Zhorina LV, Kravtsova LV. The effect of sodium humate on metabolism and resistance in highly productive poultry. Nauchnye Doki Vyss Shkoly Biol Nauki. 1991; 10: 90-5.

20. Stevenson FJ. Geochemistry of Soil Humic Substances. In: Aiken GR, McKnight DM, Wershaw RL, MacCarthy P, editors. Humic substances in soil, sediment and water. (Ed. by). New York: John Wiley \& Sons; 1985. p. 13-52.

21. Zavarzin A. Determinant of Burgi bacteria. In 2 volumes. Moscow: Mir; 1997. p. 1-800. Russian. 


\section{Natalia Matvienko, Natalia Svechkova}

HUMINIŲ MEDŽIAGŲ POVEIKIS POTENCIALIAI PATOGENINEI ŽUVŲ MIKROBŲ FLORAI

\section{Santrauka}

Tyrimo tikslas - ištirti huminių medžiagų poveiki potencialiai patogeninei mikrobų florai, išgautai iš įvairių žuvų rūšių. Tyrimai atlikti NAAS Žuvininkystes instituto ichtiopatologijos skyriuje panaudojant originalią „Djala Gold“ kompanijos (Dnepropetrovskas, Ukraina) technologiją. Tyrimo rezultatai atskleide, kad kalio humatas neturèjo reikšmingos įtakos patogeninių mikroorganizmų augimui, o pavieniais atvejais prisidèjo prie intensyvesnio bakterinès floros augimo. Taip pat jis neturi neigiamo poveikio paprastųjų karpių (Cyprinus carpio) ir baltujų katžuvių (Ictalurus punctatus) autochtoninei heterotrofinei florai žarnyne. Sidabro humatas ir metileno mèlis pasižymi dideliu antimikrobiniu aktyvumu. Gauti rezultatai yra naudingi tolesniems tyrimams bei šių medžiagų taikymui kompleksineje terapijoje, taip pat gydant bakterines žuvų infekcijas.

Raktažodžiai: huminès medžiagos, patogeninẻ žuvų mikrobų flora, baltoji katžuvè (Ictalurus punctatus), paprastasis karpis (Cyprinus carpio) 